(C) 1987 ISIJ

$$
\begin{aligned}
& \text { 液体中 } 2 \text { 孔オリフィスからの吹込みガス } \\
& \text { ジェットの相互作用 }
\end{aligned}
$$

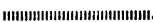

$$
\text { 小沢泰久* } * \text { 松井良行 }{ }^{*} \cdot \text { 森 一美* } \cdot \text { 佐野正道 }{ }^{*}
$$

\title{
Interaction between Gas Jets from Two Orifices in Liquid
}

\author{
Yasuhisa Ozawa, Yoshiyuki Matsui, Kazumi Mori and Masamichi Sano
}

\section{Synopsis :}

A study has been made of the interaction between gas jets from two orifices in liquid by using a high speed cinecamera. Nitrogen was injected into a mercury bath through two orifices of $0.1 \mathrm{~cm}$ in diameter $\left(d_{o}\right)$ located at the transparent vessel bottom. The distance between the two orifices $(L)$ was varied from 0.2 to $2.0 \mathrm{~cm}$. Additionally, experiments were done of helium injection into the water bath through two orifices $\left(d_{o}=0.2 \mathrm{~cm}, L=0.6 \sim 4.0 \mathrm{~cm}\right)$.

The bubbling behavior at two orifices has been classified into three patterns. "Coalescing": two adjacent bubbles growing at the orifice exits coalesce into one. "Contacting" : the adjacent bubbles contact without coalescing. "No contacting": the adjacent bubbles do not contact. "Coalescing" occurred more frequently with decreasing $L$, while "no contacting" time fraction increased with increasing $L$. The time fraction for "contacting" increased to a maximum and then decreased, as $L$ increased. The jetting behavior at two orifices was found to be strongly influenced by $L$. In certain ranges of $L$, jetting at two orifices occurred more frequently than in the case of a single orifice. A theoretical model is given to explain the interaction between gas jets from two orifices in liquid.

Key words : steelmaking; gas injection; jetting; bubbling; interactions between gas jets.

\section{1. 緒言}

吹込精錬の基礎研究として, 近年, 液体中単孔オリフィ スからのガス吹込みについて多くの研究が行われ，ガス ジェットの挙動がかなり解明されてきた ${ }^{1)-9)}$. しかし, 多孔からの吹込みガスジェットの相互作用挙動に関して は，基礎的にも実際的にも興味深い問題であるにもかか わらず，基礎研究は従来全く行われていない.

著者らは従来, $\mathrm{N}_{2}$ - 水銀 ${ }^{3) ~-5)}, \mathrm{N}_{2}$-水 ${ }^{6) 9}, \mathrm{He}^{- \text {水 }^{9)}}$ 系を 用い単孔オリフィスからの液体中ガス吹込みを行い, バ

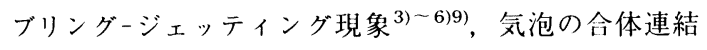

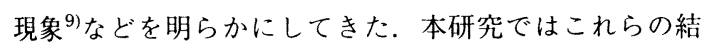
果をふまえ, 気液の密度比がかなり近い $\mathrm{N}_{2}$-水銀系およ び $\mathrm{He}$-水系を用いた 2 孔オリフィスからのガス吹込み 実験を行つた。

$\mathrm{N}_{2}$-水銀系実験では, 水銀容器の透明な底板の 2 孔才 リフィスから水銀浴中に $\mathrm{N}_{2}$ ガスを吹き込み，ガス ジェットの相互作用挙動を底板を通して高速度カメラに より直接観察した. $\mathrm{He}$-水系実験では，2 孔オリフィス から $\mathrm{He}$ ガスを水浴中へ吹き込み, 側面からの高速度撮
影を行い，オリフィス出口上方における吹き込みガス ジェットの相互作用挙動を観察し，水銀浴における底面 からの観察結果と比較した.

\section{2. 実験}

\section{$2 \cdot 1 \quad \mathrm{~N}_{2}$-水銀系実験}

実験装置を Fig. 1（a）に示した. 水銀容器はステン レス製で内径 $10 \mathrm{~cm}$, 高さ $40 \mathrm{~cm}$ である. 装置底部には

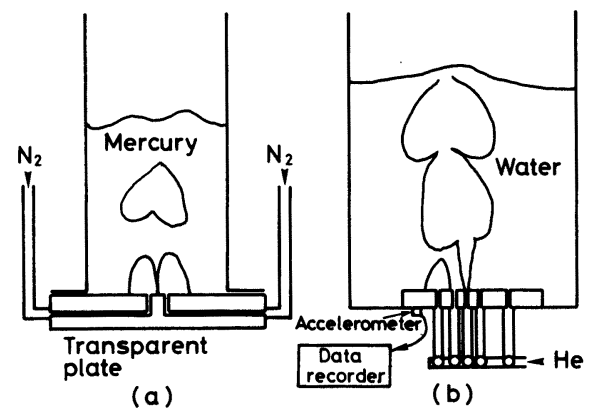

Fig. 1. Schematic drawing of experimental appa ratus.

昭和 59 年 10 月本会講演大会にて発表 昭和 62 年 1 月 14 日受付 (Received Jan. 14, 1987)

* 名古屋大学工学部 I. 博 (Faculty of Engineering, Nagoya University, Furo-cho Chikusa-ku Nagoya 464)

*2 名古屋大学大学院 (現：(株) 神戸製鋼所) (Graduate School, Nagoya University, Now Kobe Steel, Ltd.) 
中心部分に吹込み用の 2 孔オリフィスを有する透明アク リル板を用いた，オリフィス径は $0.1 \mathrm{~cm} て ゙ ， 2$ 孔オリ フィスの中心間距離 $L$ は $0.2,0.5,1.0,1.5,2.0 \mathrm{~cm}$ の 5 と㧍りとした。

容器に深さ $20 \mathrm{~cm}$ まで水銀を入れ, 高速度カメラを 装置底部から $50 \mathrm{~cm}$ 下方に設置した。 2 孔オリフィス から $\mathrm{N}_{2}$ ガスを吹き込み，装置底部の透明板を通して高 速度撮影した。フィルム送り速度は $1500 \mathrm{frames} / \mathrm{s}$ で 撮影時間は約 $3 \mathrm{~s}$ であつた。ガス流量は 1 孔当たり 55〜 $690 \mathrm{~cm}^{3} / \mathrm{s}^{\dagger}$ の範囲で変化させた。 なお，この流量範囲は みかけのマッ八数 ${ }^{4)}$ に換算すると, $0.2 \sim 2.5$ となる.

\section{$2 \cdot 2 \mathrm{He}$-水系実験}

実験装置を Fig. 1（b）に示した。水槽は $40 . \times 50 \times$ $100 \mathrm{~cm}$ の鉄製で，観察，採光用のアクリル製空を取り 付けた，水槽底部に固定した厚さ $3 \mathrm{~cm}$ のアクリル板に は一列に所定の間隔に5つオリフィスを設けた。オリ フィス直径は従来の研究6)9 2 で重点的に調べた $0.2 \mathrm{~cm}$ と した。この 5 つのオリフィスからガスを吹き込む 2 孔を 選択することにより，2 孔オリフィスの間隔を $0.6 〜 4$ $\mathrm{cm}$ の間で変化させた。 また，底部アクリル板には圧電 型加速度計を設置した。

実験には蒸留水を使用し，水深を $50 \mathrm{~cm}$ とした. $\mathrm{He}$ ガスを底部の 2 孔オリフィスから水中へ吹き込み，ガス ジェットの挙動を高速度カメラにより観察した。フィル ム送り送度は $1000 \mathrm{frames} / \mathrm{s}$ とした。 ガス流量は 1 孔 当たり $960 \sim 5800 \mathrm{~cm}^{3} / \mathrm{s}$ の範囲で変化させた。なお, この流量範囲はみかけのマッ八数に換算すると, 0.3 1.8 となる. 撮影と同時に, 気泡発生にともなう底部ア クリル板の振動の測定を加速度計により行つた。

\section{3. 実験結果および考察}

\section{$3 \cdot 12$ 孔オリフィスからのガスジェットの相互作用挙 動}

Photo. 1 に 2 孔才リフィスから形成されるガス ジェットの挙動の概念図㧍よび撮影例を $\mathrm{N}_{2}$-水銀系, $\mathrm{He}^{-}$水系の場合を対応させ， 4 種類に分類して示した. 図の $(\mathrm{a}) \sim(\mathrm{d})$ 扔のおのの左側の写真は $\mathrm{N}_{2}$-水銀系のガ スジェットの水銀浴槽底部からの撮影例である．右側の 写真は $\mathrm{He}$-水系の浴槽正面からのものである。（a ）は 2 孔オリフィスからの 2 つの気泡が合体し 1 つの気泡に

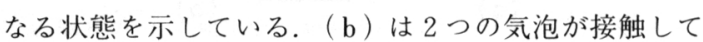
いる状態，（c）は $2 つ の$ 気泡が全く接触していない状 態を示している。また，(d) ではジェッティング314)が 起こつている。ここで，バブリングの (a)， (b)， (c)

†オリフィス出口位置の静水圧の条件下のガス流量
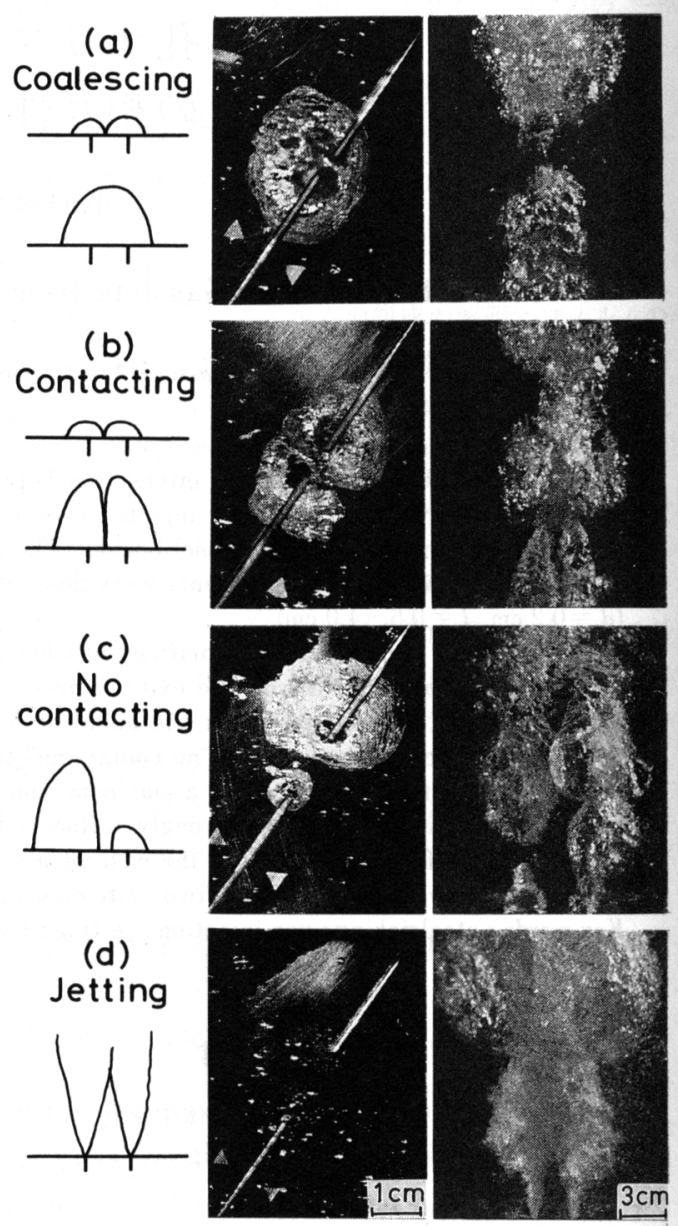

$\mathrm{N}_{2}-\mathrm{Hg}$

$\mathrm{He}-\mathrm{H}_{2} \mathrm{O}$

(a ) $\mathrm{N}_{2}-\mathrm{Hg} \quad M^{\prime}=1.0 \quad L=0.5 \mathrm{~cm} \quad \mathrm{He}-\mathrm{H}_{2} \mathrm{O} \quad M^{\prime}=0.5 \quad L=0.8 \mathrm{~cm}$

(b) $\mathrm{N}_{2}-\mathrm{Hg} \quad M^{\prime}=1.2 \quad L=1.0 \mathrm{~cm} \quad \mathrm{He}-\mathrm{H}_{2} \mathrm{O} \quad M^{\prime}=0.5 \quad L=2.4 \mathrm{~cm}$

(c) $\mathrm{N}_{2}-\mathrm{Hg} \quad M^{\prime}=1.4 \quad L=1.5 \mathrm{~cm} \quad \mathrm{He}-\mathrm{H}_{2} \mathrm{O} \quad M^{\prime}=0.5 \quad L=4.0 \mathrm{~cm}$

(d) $\mathrm{N}_{2}-\mathrm{Hg} \quad M^{\prime}=2.0 \quad L=2.0 \mathrm{~cm} \quad \mathrm{He}-\mathrm{H}_{2} \mathrm{O} \quad M^{\prime}=1.8 \quad L=2.4 \mathrm{~cm}$

Photo. 1. Jetting and various types of bubbling.

をそれぞれ“Coalescing”(合体)，“Contacting”(接触)， “No contacting”（接触なし）と呼ぶことにする.

Photo. 1(d) では両方のオリフィスにおいてジェッ ティングが起こつているが，一方がジェッティング，他 方がバブリングとなつている場合も観察された.そこで, 本研究では，一方のオリフィスからのガスジェットの挙 動に注目し，バブリングとジェッティングとを区別して それぞれの時間割合を求めた。また，バブリングについ ては, 注目しているオリフィスで生成している気泡と他 方のオリフィスで生成している気泡との相互作用挙動を "Coalescing", “Contacting", “No contacting” に分類し, さらに注目しているオリフィスからの気泡と他のオリ 

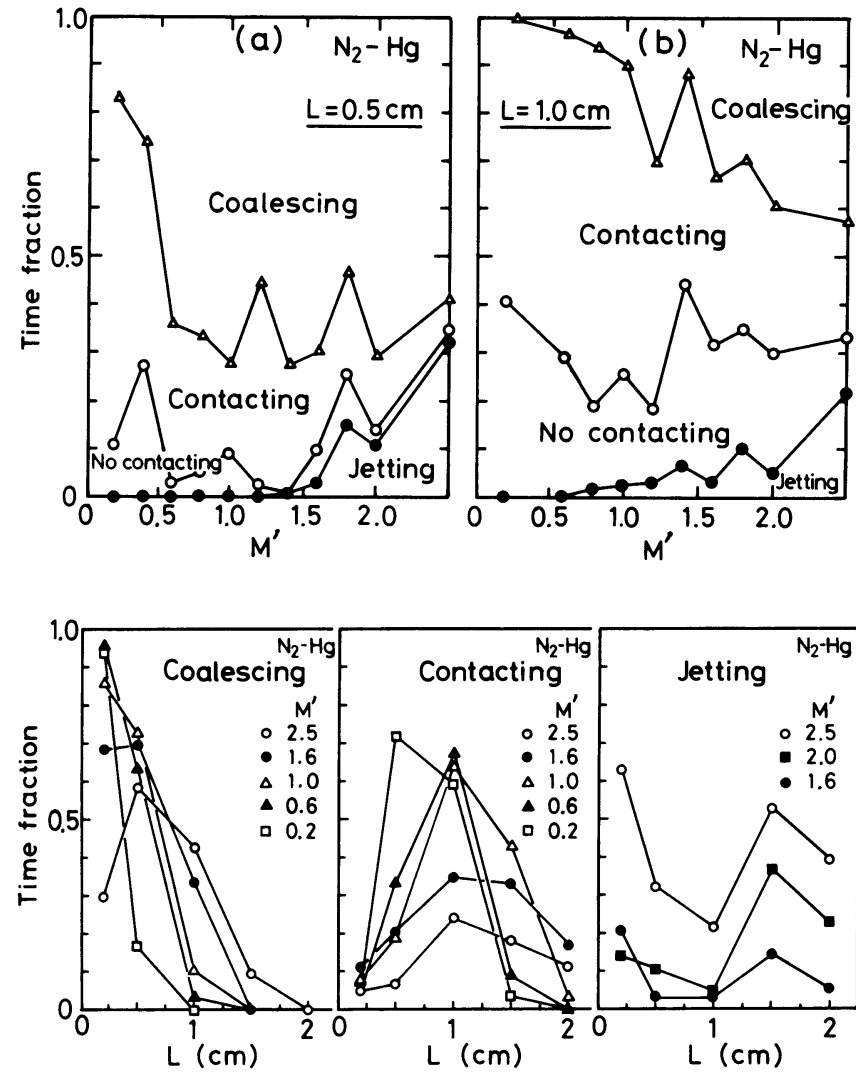

(a) (b)

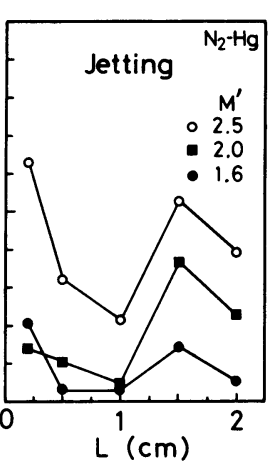

(c)
Fig. 2. Time fraction for jetting and three types of bubbling plotted against nominal mach number.
フィスからの気泡の生成開始時期の同時性について検討 を加えた。

\section{$3 \cdot 2 \quad \mathrm{~N}_{2}$-水銀系}

$3 \cdot 2 \cdot 1 \quad$ バブリングとジェッティング

バブリングの 3 つのハターン (“Coalescing”,

“Contacting”, “No contacting”）それぞれの時間割合お よびジェッティングの時閏㓶仓をみかけのマッハ数に対 して Fig. 2 にプロットした. Fig. 2(a) はオリフィス 間隔 $0.5 \mathrm{~cm}$, (b) はオリフィス閆隔 $1.0 \mathrm{~cm}$ についての 結果を示している。汹中○印がジェッティングの時間割

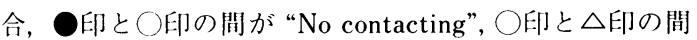
が “Contacting”の時開割命，また，残りが “Coalescing”の時閒割全を表している.

Fig. 2 より，オリフィス開隔が広い（b)においては， その間隔の狭い（a ）に比へ，苹体的に“Coalescing”の 時間割合が小さく、“No contacting”の時間割合が大き いことがわかる。また，网には“Contacting”の時間割 合は $M$ が大きいほど減少する傾们が示されている.

Fig. 3 に“Coalescing”, “Contacting”およびジェッティ
ングの時間割合をオリフィス間隔に対してプロットし た。眓に扔いて，“Coalescing”の時間割合はジェッティ ングの時間割合の大きくなる $M^{\prime}=1.6,2.5$ の場合以外に はオリフィス間隔が広いほど隇少している。

“Contacting” の時間割合はある $L$ の值において極大と なつている.また， ジェッティングは $L$ に対して一様 な変化を示さず， $L=0.2,1.5 \mathrm{~cm}$ においてその時間割合 がかなり大きくなつている.

\section{$3 \cdot 2 \cdot 2$ バブリングの特性}

バブリングの特性をより明確にするために，バブリン グの時間割合を 1 とした場合の“Coalescing”と“No contacting” の時間割合を $M^{\prime}$ と $L$ を変数とするグラフ 上に等高線としておのおの Fig. 4, 5 に示した。縦軸の $M^{\prime}=1.1$ は亜音速-音速領域の境界を示しており, これ 以上の $M^{\prime}$ ではオリフィス出口におけるガス線流速が実 際に音速に達する ${ }^{4)}$ 。

Fig. 4 において“Coalescing”の時間割合はオリフィ ス間隔が広くなるほど減少している。 また，ガス線流速 が増加するほど “Coalescing” の時間割合が大きくなる 


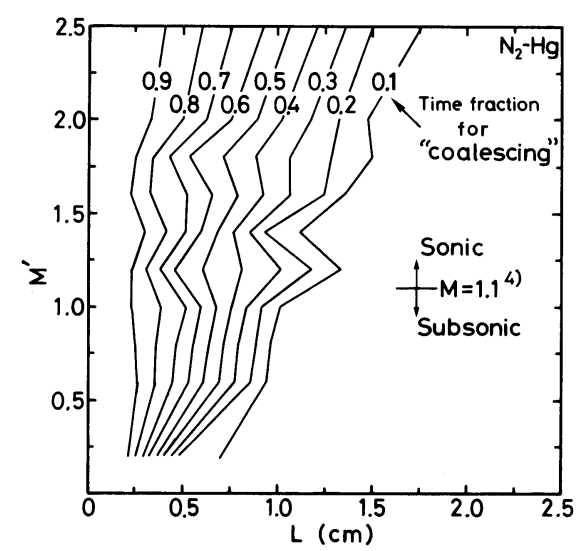

Fig. 4. The ratio of "Coalescing" to bubbling time represented in $M^{\prime}-L$ diagram.

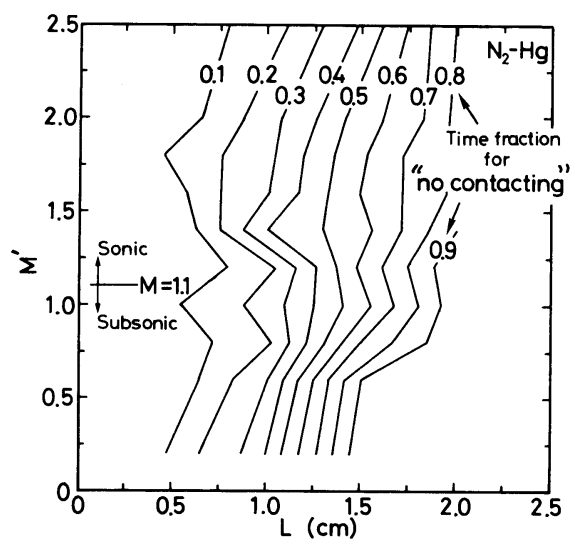

Fig. 5. The ratio of "No contacting" to bubbling time represented in $M^{\prime}-L$ diagram.

傾向が表れている. Fig. 5 から，オリフィス間隔が広 がるほど 2 孔オリフィスからの 2 つの気泡の接触は起こ りにくくなり, “No contacting” の時間割合が増加する ことがわかる．また，この時間割合はガス線流速が増加 するほど減少する傾向のあることが示されている.

\section{$3 \cdot 2 \cdot 3$ 気泡の生成開始時期の同時性}

2 孔から $2 つ の$ 気泡が同時に生成を開始した場合は,

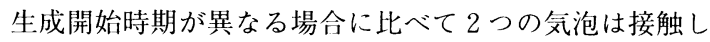
やすく，また，合体を起こしやすいと考えられる。そこ で，この同時性を定量化するため一方のオリフィスに注 目し，そのオリフィスから生成する気泡のうち，他方の オリフィスからの気泡生成と同時に生成を開始する気泡 の生成時間を合計し，その時間のバブリング全体の時間 に占める割合を求めた。このように求めた時間割合と

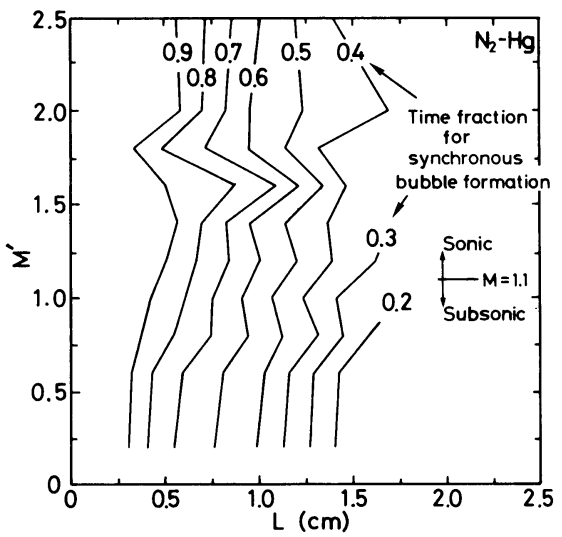

Fig. 6. The ratio of time of synchronous bubble formation to bubbling time represented in $M^{\prime}-L$ diagram.

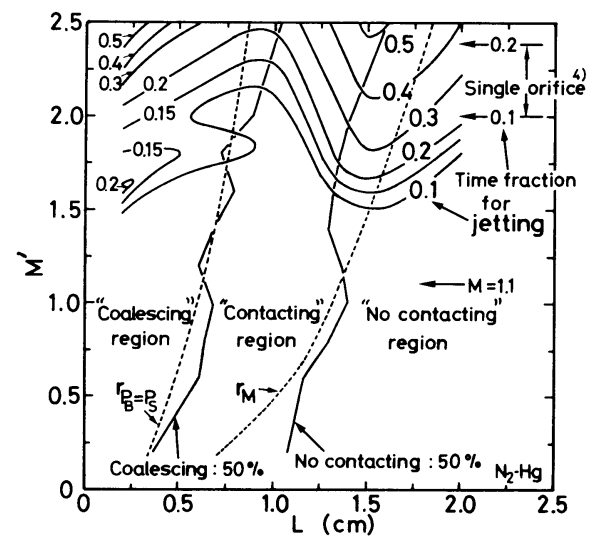

Fig. 7. Time fraction for jetting represented in $M^{\prime}-L$ diagram.

$M^{\prime}-L$ の関係を Fig. 6 に示した。网から，2つのオリ フィスからの気泡の生成開始時期の同時性はオリフィス 間隔が広がるほど低下することがわかる.

Fig. 6 と Fig. 4, 5 の比較から，2 孔オリフィスから の 2 つの気泡の命体挙動と気泡の生成時期の同時性は相 互に関連のあることがわかる。すなわち，気泡が同時に 発生しやすいオリフィス間隔の狭い場合においては

“Coalescing”の時間割合が大きくなつている (Fig. 4, 6).また，気泡の同時生成が起こりにくいオリフィス 間隔の広い場合では“No contacting”の時間割合が大 きい. (Fig. 5, 6)。これは, “Coalescing”が起こる場

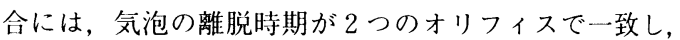
合体気泡の離脱に続く次の気泡の生成は同時に起こりゃ すくなることによる. “No contacting”の場合には気泡 
の離脱時期が- 致し難く, 次の父泡の生成も间時に起こ り難いことになる.

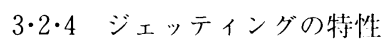

Fig. 3(c) からジェッティングには $M^{\prime}$ のほか, $L$ が関係してくることがわかる。この関係をより明確にす るために，Fig. 7 においてジェッティングの時間割命 を $M^{\prime}$ と $L$ を变数とするグラフトに等高線として示し た.四の㔫側上方には単孔オリフィスにおいて得られた ジェッティングの時間制介と $M^{\prime}$ の関係4) 知印で示し た. Fig. 7 には, Fig. 4 で “Coalescing”の時閒割会が $50 \%$ 以上となる領域を“Coalescing”領域として示し, また，Fig. 5 で“No contacting”の時䦌制へが $50 \%$ 以 上となる領域を“No contacting”領域として示し，さ らにこれら2つの開の“Contacting”の多い領域を

“Contacting”領域としてホした。なお，炍中の 2 本の 点線は $3 \cdot 3$ 節で述べるモデル計算による“Coalescing” と“Contacting”領域の境界抢よび“Contacting”と“No contacting”領域の境界である.

Fig. 7 において, “Coalescing”領域ではジェッティ ングは $L$ が小さいほど起こりやすくなつている。また， ジェッティングは“Contacting”領域では $L$ が大きいほ ど, “No contacting”頃域では $L$ が小さいほど起こりや すくなる傾问が表れている．また，単孔の場令に比べて 2 孔オリフィスの場令はジェッティングは $L$ が $0.5 \mathrm{~cm}$ 以下のオリフィス閪栾の狭い領域および $L$ が $1.5 \mathrm{~cm}$ 程度の領域に扔いてかなり起こりやすくなつている.

“Coalescing”領域で $L$ が小さいほどジェッティング が起こりやすくなるのは, オリフィス㺫近傍の 2 つの 超音速流れ ${ }^{+2}$ の䦌の相た作用が $L$ が小さくなるほど強 力になり，ガスジェットが㚣定化するためであると考え られる。また， $L=1.5 \mathrm{~cm}$ 程度に打いてジェッティン グの時間割合が大きくなるのは,オリフィス出口近傍よ りさらに上方に扔ける2つのガスジェットの間の相再作 用によると考えられるが、この梷については $3 \cdot 4$ 節に おいて, $\mathrm{He}$-水系の実験䋽果と比較し検湖を行う。

\section{$3 \cdot 3$ 気泡の合体·接触の条件についてのモデル計算}

気泡内のガス静成は笑泡界囬に均・に働くが, 吹込文 ガスの運動量による力は吹込みう们に働く。また, 気液 界面に液側から働く静水年は気泡上部において気泡下部 より低くなる。さらに，2 孔オリフィスからの気泡生成 について検討すると，2つの気泡が间時に成言を開始す る場合，気泡が相后に押し令う状態となり，2つの気泡 の間にはさまれた液体の简力は高まる，以上のような気 泡に働く力の不均一性から, 気泡内床が低い場令には,
気泡はPhoto. 1(b)，（c）に示されているように，隣 接する気泡を避けるように膨張することになり， “Coalescing”が起こり難くなる. 一方, 気泡内圧が十 分に高ければ，気泡は均一に膨張し，他方のオリフィス において成長中の気泡と合体しやすくなる.

以上のように気泡内压は気泡の合体・接触と密接な関 係があるといえる。そこで, 気泡内压を以下のように計 算した．球形気泡の半径が時間的に变化する場合，気泡 の表面の压力を $P_{R}$, 気泡から十分に離れた位置での液 体の压力を $P_{\infty}$ とすれば, 一般に次式が得られる ${ }^{10)}$.

$$
\left(P_{R}-P_{\infty}\right) / \rho_{l}=\dot{m} / R-m^{2} / 2 R^{4}
$$

ここで, $m=R^{2} \dot{R}, \dot{m}=d m / d t, \dot{R}=d R / d t, \quad \rho_{l}:$ 液 体の密度.

$P_{R}$ が気泡内压 $P_{B}$ に, $P_{\infty}$ が静水圧 $P_{s}$ に等しいと考 えれば, 次の気泡界面の運動方程式が得られる.

$$
\begin{gathered}
\left(P_{B}-P_{s}\right) / P_{s}=\left(\rho_{l} / P_{s}\right) \cdot \\
\left(R \cdot\left(\frac{d^{2} R}{d t^{2}}\right)+\frac{3}{2}\left(\frac{d R}{d t}\right)^{2}\right)
\end{gathered}
$$

ガスはオリフィスを通り気泡内へ流れ込むが, そのオ リフィス（值径 $d_{o}$ ) 内の流れに拈いて, ガス圧力 $P_{o}$ の オリフィス出口からさらに上流の压力 $P_{u}$ の位置（距離

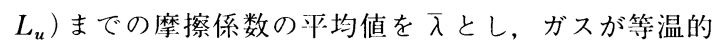
に流れると見なすと，次式が得られる ${ }^{11)}$.

$$
\begin{aligned}
& \bar{\lambda}\left(L_{u} / d_{o}\right)=\left\{1-\left(P_{o} / P_{u}\right)^{2}\right\} / \varkappa M_{u}{ }^{2} \\
& +2 \ln \left(P_{o} / P_{u}\right)
\end{aligned}
$$

また，

$$
\varkappa M_{u}{ }^{2}=q_{u}{ }^{2} /\left(P_{u} / \rho_{u}\right)
$$

ここで, $\kappa$ は比熱比, $M_{u}, q_{u}, \rho_{u}$ はそれぞれ圧力が $P_{u}$ の位置における真のマッ八数, ガス線流速, ガス密度で ある。（3），(4)式から，オリフィス出口における真の ガス線流速 $q_{o}$ は,

$$
q_{o}{ }^{2}=\frac{1-\left(P_{o} / P_{u}\right)^{2}}{\bar{\lambda} \cdot\left(L_{u} / d_{o}\right)-2 \ln \left(P_{o} / P_{u}\right)} \cdot \frac{P_{u}}{\rho_{u}}
$$

オリフィス出口位置の静水圧における体積ガス流量を $Q$, オリフィスの断面積を $A_{o}$, 等温モデルから $P_{u} / \rho_{u}$ $=P_{s} / \rho_{s}\left(\rho_{s}:\right.$ 静水压下のガス密度 $)$ とすると,

$$
Q=\frac{A_{o} P_{u}}{P_{s}} \cdot \sqrt{\left\{\frac{P_{s}}{\rho_{s}} \cdot \frac{1-\left(P_{o} / P_{u}\right)^{2}}{\bar{\lambda}\left(L_{u} / d_{o}\right)-2 \ln \left(P_{o} / P_{u}\right)}\right\}} \ldots
$$

オリフィス出口の压力 $P_{o}$ と出口位置の静水压 $P_{s}$ と の関係は垔音速領域 $\left(M^{\prime}<\sqrt{(x+1) / 2}\right)$ に打いては ${ }^{4)}$, $P_{o}=P_{s}$

であるが, 音速領域 $\left(M^{\prime}>\sqrt{(x+1) / 2}\right)$ においては4),

$P_{o} / P_{s}=\sqrt{2 /(\chi+1)} \cdot M^{\prime}$

また， $M^{\prime}$ は次式で表すことができる. 


$$
M^{\prime}=Q / a A_{o}
$$

ここで，aは室温における吹込みガス中の音速である. 生成気泡の上昇の運動方程式は次式で示される4).

$$
\rho_{l} V_{B} g+M_{g}=\frac{d}{d t}\left(\frac{11}{16} \rho_{l} V_{B} \frac{d s}{d t}\right)
$$

ここで, $s$ は気泡上昇距離, $V_{B}$ は気泡体積, $g$ は重力 加速度を表している． $M_{g}$ はガス運動量による力で次式 で与えられる4).

亜音速領域 $\left(M^{\prime}<\sqrt{(x+1) / 2}\right)$

$$
M_{g}=\frac{\varkappa}{\chi-1}\left(\sqrt{1+2(x-1) M^{\prime 2}}-1\right) A_{o} P_{s}
$$

音速領域 $\left(M^{\prime}>\sqrt{(x+1) / 2}\right)$

$$
M_{g}=\left(\sqrt{2(x+1)} M^{\prime}-1\right) A_{o} P_{s}
$$

また，気泡が Fig. 8 右上に示すような形状であると仮 定すると気泡体積 $V_{B}$ は次式で表される.

$$
V_{B}=\pi\left(2 R^{3}+3 R^{2} s-s^{3}\right) / 3 \cdots
$$

オリフィス出口位置の静水压について補正した気泡体積 を $V_{s}$ とすれば，

$$
\begin{aligned}
& P_{B} V_{B}=P_{s} V_{s} \\
& Q=d V_{s} / d t
\end{aligned}
$$

(14) 式の両辺を時間 $t$ で微分すると,

$$
\frac{P_{B}}{P_{S}} \frac{d V_{B}}{d t}+\frac{d\left(P_{B} / P_{s}\right)}{d t} \cdot V_{B}=Q
$$

$r$ を気泡底面半径とすれば,

$$
r=\sqrt{R^{2}-s^{2}}
$$

初期条件として， $t=0$ において $R=d_{o} / 2, d R / d t=0$, $P_{B}=P_{s}, Q=Q_{i}\left(Q_{i}\right.$ : 設定した吹込み流量)を用い, (2) ，(6)～(13)，(16)，(17) 式を連立させ，Runge-KuttaFehlberg 4 次法により数值計算し, $P_{B}, Q, r$ の経時変 化を求めた。な挍，簡単化のため， $P_{u}$ はオリフィス出 口位置から十分に離れた位置に拈ける压力であり，初期 条件により決まる値のまま一定であると仮定した。

Fig. 8 に気泡内压 $P_{B}$, ガス流量 $Q$ および気泡底面半 径 $r$ の経時変化の計算例を示した ${ }^{\dagger 3}$. 図において, $P_{B}$ は生成開始直後に瞬間的に上昇し，ガス流量 $Q$ は急激 に減少している， $P_{B}$ は極大值に達した後，気泡の膨張 にともない低下し，静水圧より低くなり，極小值に達し た後，再び上昇，下降を繰り返し，減衰振動している．

本節 $3 \cdot 3$ のはじめにおいて気泡内压が高い場合には “Coalescing”が起こりやすいと考えたが，その気泡内 圧の高い状態は Fig. 8 では気泡生成開始時から A 点ま

†3 Fig. 8 は $\bar{\lambda} L_{u} / d_{o}=10$ とした計算例であるが, $\bar{\lambda} L_{u} / d_{o}$ が変化すれば， $P_{B} ， Q ， r$ の経時変化はまた異なつた計算結果になる。ただ，後述 する “Coalescing”と“Contacting”領域の境界扰よび “Contacting” と“No contacting”領域の境界についての計算結果は $\bar{\lambda} L_{u} / d_{o}$ の值に ほとんど依存しない。

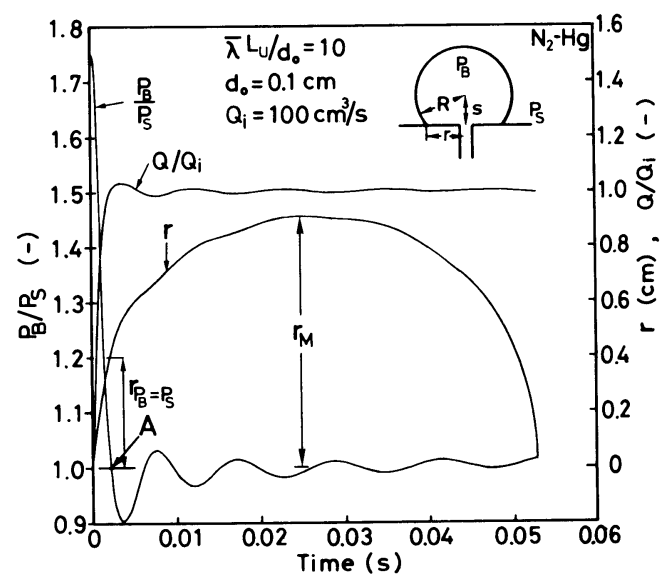

Fig. 8. Predicted pressure, bubble base radius and gas flow rate fluctuations.

での範囲において見られる。そこで，A点における気泡 底面半径を $r_{P_{B}=P_{s}}$ とすれば, $L<r_{P_{B}=P_{s}}$ の領域におい ては，2 孔オリフィスからの気泡の生成開始時期が一致 しなくとも, 気泡内压が高い状態で他方のオリフィス出 口位置まで気泡底面外凬が達することができ, 合体が起 こりやすいといえる。また，命体が起こると 2 つオリ フィスにおける気泡の離脱時期が一致し, 続く気泡生成 は同時に起こりやすくなる. したがつて $L<r_{P_{B}=P_{b}}$ の 領域においては “Coalescing”が起こりやすく，また， 気泡の生成開始の同時性が高いと考えられる.

Fig. 8 に示すように気泡底面半径 $r$ の極大值を $r_{M}$ と すると，オリフィス閪隔 $L$ が $r_{M}$ 以下の場令には 2 つ のオリフィスからの気泡の生成が独立に起こつた場合で あつても“Contacting”が起こりやすい.しかし Lが $r_{M}$ 以上の場命には“Contacting”が起こり難くなる. したがつて $r_{P_{B}=P_{s}}<L<r_{M}$ は“Coalescing”は起こり 難いが，“Contacting”は起こりやすい領域であるとい える.

以上の検討から, $L<r_{P_{B}=P_{s}}, r_{P_{B}=P_{s}}<L<r_{M}, r_{M}$ $<L の$ 各領域は, 実験結果から求めた“Coalescing”, “Contacting”, “No contacting”の各領域に対応するこ とがわかる。そこで, “Coalescing”, と“Contacting” 領域の境界に対心する $L=r_{P_{B}=P_{s}}$ および “Contacting” と“No contacting”領域の境界に対忍する $L=r_{M}$ の計 算結果を Fig. 7 につの点線で示した。网において, 計算結果は実験結果とかなり一致している。この一致か ら，本節において推定した気泡の合体・接触についての 機構が実際にもかなり当てはまることがわかつた。 


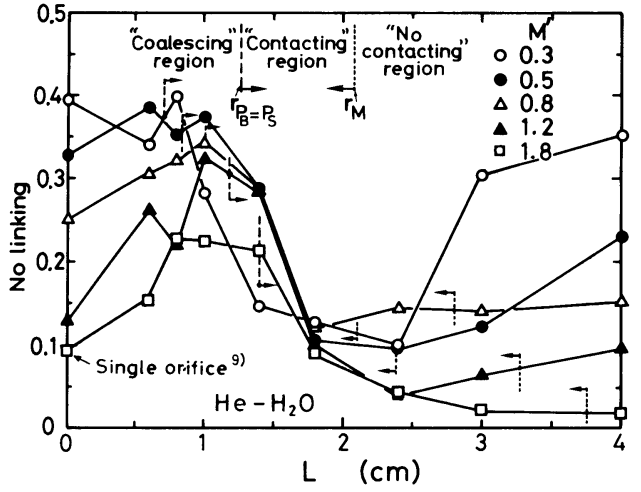

Fig. 9. Time fraction for "No linking" plotted against distance between two orifices.

\section{$3 \cdot 4$ He-水系}

$\mathrm{N}_{2}$-水銀系では装㯰底部からガスジェットの相西作用 挙動を観祭したが, その上方の浴内部のジェットの挙動 は不明である.そこで, 水銀浴内部のガスジェットの挙 動を推定するため $\mathrm{He}$-水系実験を行い，ガスジェット を側面から観祭し，オリフィス川口近傍の気泡の令体・ 接触挙動とより.上部のガスジェットの挙動の関係を調べ た.

Fig. 9 にHe-水系に打いて求めた“No linking”の時 間割合とオリフィス闆隔 $L$ の関係を示した。ここで,

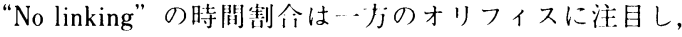
その出口で気泡が離脱した時梷からつぎの気泡が上昇し つつある離脱気泡に介体連絬されるまでの時間を“No linking”の時閏として求めた ${ }^{+4}$ 。沙中の破線と点線は $3 \cdot 3$ 節の計算を $\mathrm{He}$-水系について行つた絬果で，おのお の “Coalescing”と“Contacting”の領域の境界扰よび “Contacting”と“No contacting”の領域の境界を示す. 図には単孔オリフィス $(L=0)$ から水浴中へ $\mathrm{He}$ ガスを

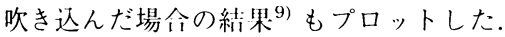

Fig. 9 において, $L=0 \sim r_{P_{B}=P_{s}}$, の “Coalescing” 領 域では, “No linking”の時䦌制令はオリフィス閶隔が 狭くなるほど小さくなり, 単孔の絬果に近づく傾们があ る。これは，オリフィス䦌滑が狭くなるほど，2つの才 リフィスからの気泡は介体しやすく，その場介，2 孔か らのガスジェットが 1 つのガスジェットとして挙動し, 気泡先端部におけるガスジェットの動压が増加し, 気泡 が連結しやすいことによる。

† 一方のオリフィスで成長中の父泡は上部の離脱父泡と令体連結され， 他方のオリフィスからの気泡はその離脱㻌泡と命体していないという

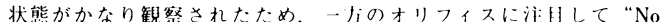
linking”の時間割公を求めた。

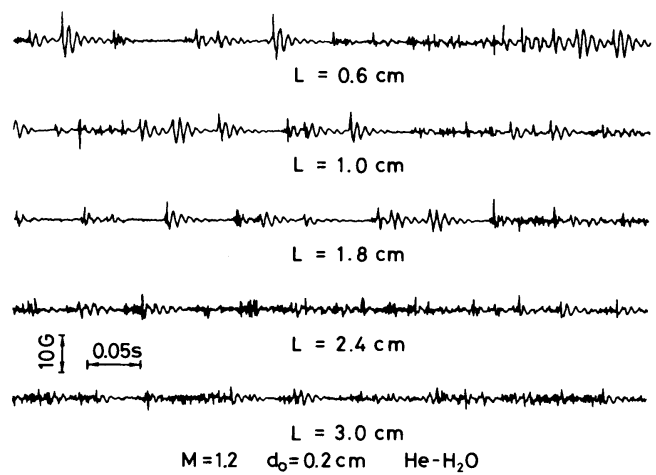

Fig. 10. Bubble knocking measured by accelerometer.

㲸中, $L=r_{P_{B}=P_{s}} \sim r_{M}$ の “Contacting”領域では, “No linking”の時間割命はオリフィス間隔が広いほど著しく 減少している。 これは， $\mathrm{N}_{2}$-水銀系実験について Fig. 6 に関連して述べたようにこの領域においては気泡が交 互に発生し，全体として気泡間隔が狭くなり，その結果， 気泡の合体連結が起こりやすくなるためである.

前述したように $\mathrm{N}_{2}$-水銀系の実験より “Contacting” 領域においてジェッティングの時間割合がオリフィス間 隔の広がるほど増加し, 単孔に比べてかなりジェッティ ングが起こりやすくなる (Fig. 7).この現象は “Contacting”領域では気泡の合体連結が起こりやすく なるという本節の観察結果と関係づけて次のように説明 される，すなわち，前報6)において述べたようにジェッ ティングは一般に浴内の不規則な流れによつておこる液 の動压の変動により不安定になるが，2 孔オリフィスの 場合, “Contacting”領域においてはオリフィス出口上 方での気泡の合体連結が起こり，そのため浴内の液の動 有の変動が小さくなりジェッティングが安定になりやす w.

Fig. 10 に $\mathrm{He}$-水系実験において得られた加速度計に よる浴槽底板の振動の測定例を示した。図において，才 リフィス間隔の狭い $L=0.6,1.0 \mathrm{~cm}$ の場合には頻度は 小さいが大きな衝撃が観察されている.しかし,オリフィ ス閒隙が広くなると，小さな衝撃が多数観察されるよう になる.これは, Fig. 9 と比較すると, Fig. 10 の $L=$ $0.6,1.0 \mathrm{~cm}$ の結果は “Coalescing”領域にあり, $L=1.8$, $2.4,3.0 \mathrm{~cm}$ の結果は“Contacting”領域にあることに よる.すなわち, “Coalescing”領域においては合体に より大気泡が生成し, 衝撃強度も大きくなるが, “Contacting” 領域においては，気泡が交互に生成し， 上部離脱気泡と連続的に合体連結されるため，オリフィ 
ス出口の気泡が十分成長する前にその上部気泡に吸収さ れ，大気泡の生成は抑制される。このため，小さな衝撃 が多数観察されることになる.

\section{4. 結言}

$\mathrm{N}_{2}$-水銀系抄よび $\mathrm{He}$-水系に扰いて 2 孔オリフィスか らのガス吹込み実験を行い, 以下の結果を得た.

（1） 2 孔オリフィスからの 2 つの成長中の気泡の相 互作用挙動はつぎのように分類できた。“Coalescing” : 2 つの気泡が合体し1つになる. “Contacting”：2つの 気泡が接触はするが合体しない. “No contacting”：接 触もしない。

（2）オリフィス間隔が狭い場合, “Coalescing”が 起こりやすく,オリフィス間隔が広がるほど, “No contacting”が起こりやすくなる. “Contacting”は他の 2 つの挙動の中間的な現象であり，その時間割命はある オリフィス間隔に打いて極大となる。これら各現象の起 こりやすい条件をみかけのマッ八数とオリフィス間隔の 関係図で“Coalescing”, “No contacting”扩よび “Contacting”領域の 3 つの領域に分けて示した.

(3) “Coalescing”領域では2つのオリフィスから の気泡は同時に発生し, “No contacting”領域では気泡 は交互に発生する傾向がある。その中間の “Contacting” 領域ではオリフィス間隔が広がるほど気泡の交互発生の 起こる頻度が高くなる。

(4) “Contacting”領域と “No contacting”領域の 境界付近の吹込み条件の場合には離脱気泡と生成中の気 泡との合体連結が起こりやすく，また，ジェッティング
の時間割合が大きい。

（5）浴槽底部に設置した加速度計を用いた測定にお いて, “Coalescing”領域では大きな衝撃が観察され， “Contacting”領域では小さな衝撃が観察された。

（6）気泡内の厈力変化の計算から “Coalescing” と “Contacting”領域の境界および “Contacting”と“No contacting”領域の境界の吹込み条件を理論的に求めた。 この計算結果は実験結果とかなりょく一致した.

本研究の一部は, 第 23 回東レ研究助成金および昭和 60 年度文部省科学研究費補助金奨励研究 (A)によつた ことを付記して謝意を表します。

なお，本研究における実験結果の整理の計算に名古屋 大学大型計算機センターを利用した。

\section{文献}

1) A. E. Wraith and M. E. Chai.Kl.Ey: Advances in Extractive Metallurgy, ed. by M. J. Jonfs (1977), p. 27 [IMM London]

2) E. O. Hokfele and J. K. Brimacombe: Metall. Trans. B, $10(1979)$, p. 631

3) K. Mori, Y. OzaWa and M. Sano: Metall. Trans. B, 10 (1979), p. 679

4) 小沢泰久, 森 一美, 恢野正道：鉄と鋼，67 (1981), p. 2655

5 ）小沢泰久，森一美：鉄と鋼，68 (1982), p. 90

6）小沢泰久, 森 …美：鉄と鋼，68 (1982), p. 98

7 ) M. J. MCNallian and T. B. King : Metall. Trans. B, 13 (1982), p. 165

8) L. Farias and D. G. C. Robertson: Injection Phenomena in Extraction and Refining, compiled by $A$. E. WraITH (1982), E 1 25

9 ) 小沈泰久，森 一美: 鉄と鋼, 72 (1986), p. 426

10）今井 功: 流体力学 (前編) (1975), p. 97 [裳華房]

11）原田幸大: 流体打学・水打学演習 (1977), p. 360 [梖書店] 